\title{
REACTIVATION OF THE FEULGEN REACTION OF RAM SPERMATOZOA BY DITHIOTHREITOL
}

\author{
G. ESNAULT \\ I.N.R.A.-Station de Physiologie de la Reproduction, \\ Centre de Recherches de Tours, Nouzilly 37380 Monnaie, France
}

(Received 8th August 1972)

Reduction in the intensity of staining by the Feulgen reaction for DNA has been demonstrated in mammalian spermatids during spermiogenesis (Gledhill, Gledhill, Rigler \& Ringertz, 1966) and in spermatozoa during transit through the epididymis (Gledhill, 1966, 1971 ; Bouters, Esnault, Ortavant \& Salisbury, 1967; Bouters, Esnault, Salisbury \& Ortavant, 1967). On the other hand, it has been reported that there is a reactivation of the Feulgen reaction for spermatozoa in the female genital tract (Chang, 1959; Esnault, Orgebin-Crist \& Ortavant, cited by Orgebin-Crist, 1969). As these variations in the intensity of the Feulgen reaction are not related to changes in DNA concentration as measured by ultraviolet absorption, it is likely that they are due to chemical alteration of deoxyribonucleoprotein (Gledhill et al., 1966).

This paper gives the results of measurements of Feulgen staining in germinal cells during spermatogenesis and transit through the epididymis in the ram and reports a reactivation of the Feulgen reaction in spermatozoa after treatment with dithiothreitol, a reagent which reduces disulphide bonds (Cleland, 1964).

Specimens from fourteen ile-de-France rams were used. Smears were made by touching pieces of testis against a slide. This gave a single layer of well separated nuclei. The preparations were immediately fixed in a mixture of three vols $95 \%$ ethanol and one vol. acetic acid for $1 \mathrm{hr}$, or by exposure to formaldehyde vapour for $15 \mathrm{~min}$. Smears of spermatozoa from the head, body and tail of the epididymis, and ejaculated spermatozoa collected into an artificial vagina before slaughter were fixed in the same way. Ejaculated spermatozoa were treated for 15 to 45 min with millimolar dithiothreitol (DTT) buffered to $\mathrm{pH} 9$ with sodium borate before preparing smears (Calvin \& Bedford, 1971). Absorption measurements were made on a Zeiss ultraviolet microspectrophotometer (USMP 1) by scanning the nuclei and integrating the optical densities (Caspersson, 1936). The preparations were mounted in glycerol on Quartz slides. Measurements were made at $265 \mathrm{~nm}$ and $280 \mathrm{~nm}$ on germinal cells from the testis treated with $1 \mathrm{mg}$ $\mathrm{RNase} / \mathrm{ml}$ distilled water at $40^{\circ} \mathrm{C}$ for $4 \mathrm{hr}$ (Amano, 1962) and on spermatozoa. The total extinction values have been corrected for non-specific light losses measured at $315 \mathrm{~nm}$. Measurements were performed at $560 \mathrm{~nm}$ on material prepared on glass slides and stained by the Feulgen reaction (Bouters et al., 1967).

Ultraviolet absorption measurements of DNA showed the differences in ploidy which are found in primary and secondary spermatocytes and in round 


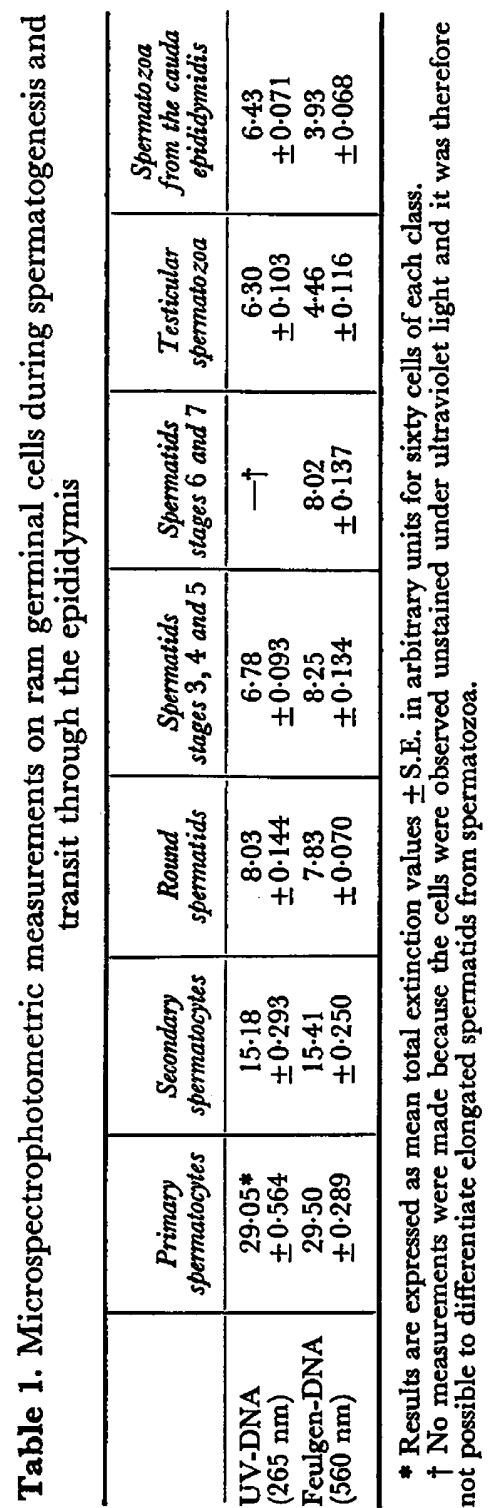


spermatids (Table 1). At the start of the phase of spermatid elongation during stages 2 and 3 of the cycle of the seminiferous epithelium (Ortavant, 1958), there was a slight reduction in total extinction. The reason for this is not known. Ultraviolet measurements in elongated spermatids during the remainder of spermiogenesis, and in spermatozoa during passage through the epididymis showed no differences in DNA concentration. The curves of measurements made at $265 \mathrm{~nm}$ and at $280 \mathrm{~nm}$ were parallel throughout spermatogenesis and in the spermatozoa.

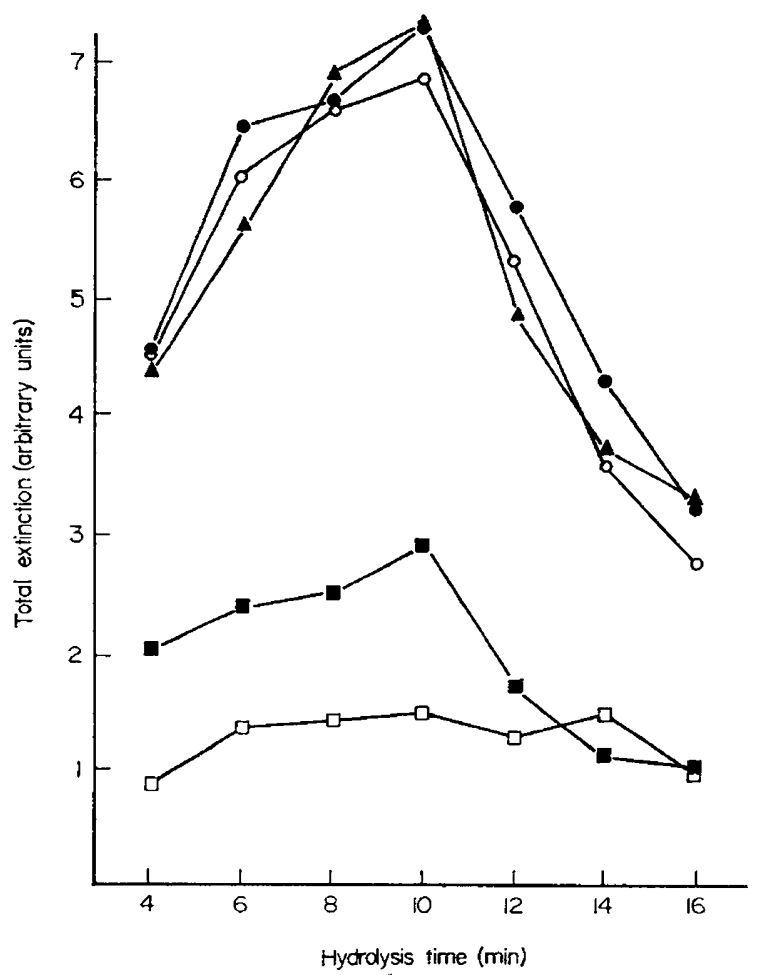

Text-Fig. 1. Influence of the acid-hydrolysis period ( $\mathrm{N}-\mathrm{HCl}$ at $60^{\circ} \mathrm{C}$ ) on the staining of spermatids and spermatozoa by the Feulgen reaction. Mean of thirty nuclei for each class (total extinction at $560 \mathrm{~nm}$ in arbitrary units). $\bullet$, Round spermatids; $\Delta$, spermatids at stages 3,4 and $5 ; 0$, spermatids at stages 6 and $7 ; 0$, testicular spermatozoa; $\square$, spermatozoa from the cauda epididymidis,

In the spermatocytes and in the round spermatids, measurements of the total extinction of the Feulgen-stained nuclei were practically identical to the ultraviolet absorption measurements. However, at stage 8 of the cycle, and the moment of release of spermatozoa in the seminiferous tubules, there was a $45 \%$ reduction in the concentration of Feulgen-staining material (Table 1). This phenomenon could not have been due to a change in sensitivity to acid hydrolysis during the Feulgen reaction, because the optimum time for hydrolysis was the same for each type of cell (Text-fig. 1). During the passage of spermatozoa through the epididymis, there was a further, but less marked, reduction in Feulgen staining. 
After treatment by DTT and staining by the Feulgen reaction, $52 \%$ to $84 \%$ of the ejaculated spermatozoa, depending on the specimen, stained very densely with a total extinction identical to that of the nuclei of round or elongating spermatids. The nuclear chromatin of this group of spermatozoa was slightly granular. The other spermatozoa showed nuclear staining comparable to that in control spermatozoa (Table 2). This treatment did not have a significant effect on nuclear size.

As there was no change in ultraviolet absorption during the completion of spermiogenesis, the sudden reduction in the intensity of Feulgen staining accompanying the differentiation of elongated spermatids into spermatozoa could not have been due to a reduction in the quantity of DNA. Just before this reduction in Feulgen staining, there is an increase in the intensity of staining by alkaline Fast Green (Alfert \& Geschwind, 1953) and by Sakaguchi's test (Liebman, 1951) suggesting changes in the basic nuclear proteins. The reactivation of the Feulgen reaction in DTT-treated spermatozoa implies that disulphide groups play an

Table 2. Effect of dithiothreitol on total extinction at $560 \mathrm{~nm}$ of ram spermatozoa stained by the

Feulgen reaction

\begin{tabular}{l|c|c|c}
\hline \multirow{1}{*}{ Treatment } & \multicolumn{3}{|c}{ Time of incubation } \\
\cline { 2 - 4 } & $15 \mathrm{~min}$ & $\mathbf{3 0 \mathrm { min }}$ & $\mathbf{4 5 \mathrm { min }}$ \\
\hline Borate buffer alone & $3.56 *$ & 3.67 & 3.36 \\
& \pm 0.037 & \pm 0.040 & \pm 0.053 \\
\hline Dithiothreitol with & & & \\
borate buffer & & & \\
Class 1 & 3.64 & 4.39 & 4.90 \\
Class 2 & \pm 0.035 & \pm 0.045 & \pm 0.063 \\
& 7.91 & 8.21 & 8.08 \\
& \pm 0.074 & \pm 0.039 & \pm 0.069 \\
\hline
\end{tabular}

Untreated spermatozoa had a total extinction of $3 \cdot 43 \pm 0 \cdot 016$.

* Results expressed as mean total extinction values \pm S.E. in arbitrary units for thirty cells of each class.

important rôle in the reaction. Loir (1970) has shown that although there is practically no change in the intensity of staining of SH groups during the course of spermiogenesis, the staining of disulphide groups increases up to stage 7 . Furthermore, spermatozoa are known to be very rich in the basic disulphidecontaining amino acid, cystine (Bril-Petersen \& Westenbrinik, 1963; Henricks, 1965; Chamberlain \& Walker, 1965; Coeling, Rozijn \& Monfoort, 1969).

In the female genital tract, there is a $25 \%$ increase in the intensity of Feulgen staining in ejaculated rabbit spermatozoa without any variation in the amount of DNA as measured by ultraviolet absorption (Esnault et al., cited by OrgebinCrist, 1969). Perhaps this phenomenon is related to the reactivation of the Feulgen reaction which occurs when spermatozoa are treated with dithiothreitol.

The author wishes to thank Dr R. Ortavant for his valuable comments during 
the preparation of this paper and Mr J. G. Nicolle for technical assistance. I am also grateful to Dr A. G. Davies for translating the article.

\section{REFERENCES}

Alfert, M. \& Geschwind, I. I. (1953) A selective staining method for the basic proteins of cell nuclei. Proc. natn. Acad. Sci. U.S.A. 39, 991.

Amano, M. (1962) Improved techniques for the enzymatic extraction of nucleic acids from tissue sections. 7. Histochem. Cytochem. 10, 204.

Bouters, R., Esnault, C., Ortavant, R. \& Salisbury, G. W. (1967) Gomparison of DNA revealed by Feulgen and by ultra-violet light in rabbit spermatozoa after storage in the male efferent ducts. Nature, Lond. 213, 181.

Bouters, R., Esnault, G., Salisbury, G. W. \& Ortavant, R. (1967) Discrepancies in analyses of deoxyribonucleic acid in rabbit spermatozoa involving Feulgen staining (Feulgen-DNA) and ultraviolet light absorption (UV-DNA) measurements. F. Reprod. Fert. 14, 355.

Bril-Petersen, E. \& Westenbrinik, H. G. K. (1963) A structural basic protein as a counterpart of deoxyribonucleic acid in mammalian spermatozoa. Biochim. biophys. Acta, 76, 152.

Calvin, H. I. \& Bedrord, J. M. (1971) Formation of disulphide bonds in the nucleus and accessory structures of mammalian spermatozoa during maturation in the epididymis. F. Reprod. Fert. Suppl. 13,65 .

Gaspersson, T. (1936) Uber den chemischen Aufbau der Strukturen des Zellkernes. Skand. Arch. Physiol, 73, Suppl. 8.

Ghamberlain, P. J. \& Walker, P. M. B. (1965) The thermal denaturation of nucleo-protein in boar sperm. F. molec. Biol. 11, 1.

Chang, M. C. (1959) Fertilizing capacity of spermatozoa. In: Recent Progress in the Endocrinology of Reproduction, p. 153. Ed. C. W. Lloyd. Academic Press, New York.

Gleland, W. W. (1964) Dithiothreitol, a new protective reagent for SH groups. Biochemistry, N.Y. 3, 480.

Gozling, J. P., Rozijn, T. H. \& Monpoort, G. H. (1969) Isolation and partial characterization of a basic protein from bovine sperm nuclei. Biochim. biophys. Acta, 188, 353.

GredhrL, B. L. (1966) Studies of the DNA content, dry mass and optical area of bull spermatozoa heads during epididymal maturation. Acta vet. scand. 7, 131.

GuEdHILL, B. L. (1971) Changes in deoxyribonucleoprotein in relation to spermateliosis and the epididymal matui ation of spermatozoa. F. Reprod. Fert. Suppl. 13, 77.

Gledhill, B. L., Gledhill, M. P., Rigler, R., JR \& Ringertz, N. R. (1966) Changes in deoxyribonucleoprotein during spermiogenesis in the bull. Expl Cell Res. 41, 652.

HeNRICks, D. M. (1965) Isolation and characterization of a basic keratin-like protein of mammalian spermatozoa. Diss. Abstr. 26, 1320.

Liebman, E. (1951) Permanent preparations with the Thomas arginine histochemical test. Stain Technol. $26,261$.

LorR, M. (1970) Introduction à l'étude des métabolismes de l'acide ribonucleique et des protéines dans les spermatocytes et les spermatides du belier (Ovis aries). Thèse 3e cycle, Université Caen.

Orgebin-Grist, M. C. (1969) Studies on the function of the epididymis. Biol. Reprod. Suppl. 1, 155.

Ortavant, R. (1958) Le cycle spermatogénétique chez le belier. Thèse Doc. Sci., Paris. 